\title{
Greenhouse Gases and Ammonia Emission Factors from Livestock Buildings for Pigs and Dairy Cows
}

\author{
Wojciech Rzeźnik*, Paulina Mielcarek \\ Institute of Technology and Life Sciences \\ Biskupińska 67, 60-463 Poznań, Poland
}

Received: 31 March 2016

Accepted: 2 April 2016

\begin{abstract}
The aim of this study was to review research papers with gas emission data from livestock buildings that were published between 1997 and 2015. The review focused on three gases: $\mathrm{NH}_{3}, \mathrm{~N}_{2} \mathrm{O}$ and $\mathrm{CH}_{4}$ and two animal species: pigs and dairy cows. The results of the review are presented in different units, which makes it difficult to compare the data. For this purpose, the gas emission factors were converted to $1 \mathrm{LU}$ (livestock unit $=500 \mathrm{~kg}$ ).

The median of $\mathrm{NH}_{3}$ emission factors for pigs $\left(45.6 \mathrm{~g} \cdot \mathrm{day}^{-1} \cdot \mathrm{LU}^{-1}\right)$ was almost twice that of dairy cows $\left(26.7 \mathrm{~g} \cdot \mathrm{day}^{-1} \cdot \mathrm{LU}^{-1}\right)$. For $\mathrm{N}_{2} \mathrm{O}$ the emission factor median for pigs $\left(3.2 \mathrm{~g} \cdot \mathrm{day}^{-1} \cdot \mathrm{LU}^{-1}\right)$ was more than twice that of dairy cows $\left(1.5 \mathrm{~g} \cdot\right.$ day $\left.^{-1} \cdot \mathrm{LU}^{-1}\right)$. Also for $\mathrm{CH}_{4}$, the median of emission factors for dairy cows (302.5 $\left.\mathrm{g} \cdot \mathrm{day}^{-1} \cdot \mathrm{LU}^{-1}\right)$ was more than three times higher than the value for pigs $\left(85 \mathrm{~g} \cdot \mathrm{day}^{-1} \cdot \mathrm{LU}^{-1}\right)$. The variation in the gas emission factor values for pigs and dairy cows is large. This may be due to the following reasons: geographical location, animal species, feed composition, housing and ventilation system or time of measurements. Therefore, there is a need to continue gas emission monitoring research in order to more precisely determine the values of these gas emission factors for pig and dairy production facilities. Measurement procedures should be standardized including the number of measuring days/months, frequency of sampling, measurement equipment and unit of gas emission factor units. Using common methodology for measuring gas emission will allow better comparisons between emission factors for livestock buildings and housing systems and between countries and animal species.
\end{abstract}

Keywords: greenhouse gases, ammonia, emission factor, pigs, dairy cow

\section{Introduction}

The impact of animal agriculture on the environment - especially on climate and ecosystems - is an important

*e-mail: w.rzeznik@itp.edu.pl problem in the time of intensification and consolidation of livestock production. This consolidation creates both policy and scientific concerns. Agriculture, especially livestock production, is a significant source of gaseous pollutants. The most important are the two greenhouse gases methane $\left(\mathrm{CH}_{4}\right)$ and nitrous oxide $\left(\mathrm{N}_{2} \mathrm{O}\right)$, plus ammonia $\left(\mathrm{NH}_{3}\right)$ [1-4]. 
Methane is produced during anaerobic fermentation of organic compounds contained in feed and manure. It is emitted as a byproduct of enteric fermentation, wherein the carbohydrates are degraded by microorganisms in the digestive tract of animals (mainly ruminants) and during anaerobic decomposition of manure. The emission of nitrous oxide in agriculture is a process still not completely known. This gas is emitted from manure as an intermediate product of nitrification/denitrification in conditions of low oxygen availability [5-8]. Methane and nitrous oxide have high global warming potential, 23 and 296 times greater than carbon dioxide, respectively [9]. Ammonia is produced during decomposition of protein substances. This process occurs under anaerobic conditions and is intensified by high temperatures and humidity [4-5, 10]. $\mathrm{NH}_{3}$ emission causes many negative environmental effects such as eutrophication and acidification of ecosystems [11-12], and decreases in biodiversity [13].

In "The role of livestock in climate change" the FAO reports that agriculture contributes to $18 \%$ of global anthropogenic emissions of greenhouse gases, including $9 \%$ of $\mathrm{CO}_{2}$ emissions, $34 \%$ of $\mathrm{CH}_{4}$ emissions, and $65 \%$ of $\mathrm{N}_{2} \mathrm{O}$ emissions [14]. However, this calculation also included deforestation of certain areas of the world to provide feed (mainly grazing cattle). Whereas, according to data published by the FAO in "Agri-Environmental Indicators," this sector was responsible for $94.17 \%$ of global $\mathrm{NH}_{3}$ emissions in 2009 [15]. The inventory of gaseous pollutants is carried out based on international methodology of the Intergovernmental Panel on Climate Change (IPCC) and the European Monitoring and Evaluation Programme (EMEP), for which the calculations mainly use standard (theoretical) emission factors of greenhouse gases and ammonia, whose values differ from factors obtained during research [16]. The differences may be due to various factors, including genetics of animals, diet, housing and manure management systems, ventilation system type, weather conditions, and building locations [17-19].

The aim of this study was to summarize and compare existing emission factors of $\mathrm{CH}_{4}, \mathrm{~N}_{2} \mathrm{O}$, and $\mathrm{NH}_{3}$ from animal production facilities. This paper concerns emissions from livestock buildings for two species of animals: pigs and dairy cows. The data presented identifies housing systems, building types, the time (season) of data collection, and the country.

\section{Gas Emission Measurements}

Gas emission factors from animal production can be determined using various methods regarding how gases and ventilation rates are measured and where, how frequent, and how long samples are collected. The data found in the literature are typically done under different conditions: laboratory (climatic chamber) [20-22], research farms (experimental room) [23-24], and commercial production (livestock building) [25-27].

Each of the data collected under the different conditions has advantages and disadvantages. Studies at the laboratory scale and at research production sites are more basic, or fundamental research. They enable scientists to do preliminary observations and assessment of the phenomena occurring in livestock buildings. During such data collection, the large number of parameters affecting the experiment are controlled and potential sources of uncertainties are easier to identify. Although the emission factors determined in that way are more precise, they do not completely represent the specifics during actual animal production conditions. The research usually lasts for a single production cycle for pigs [28-29] or for a selected few weeks or months for dairy cows [3031]. Measurements in commercial production conditions usually increase the number of variables, which are difficult to control and affect the measured values. On the other hand, such experiments provide information about the impact of the season and the time of day on gas emissions, because they are conducted in real time and under real weather conditions. This type of research is generally made within shorter time periods [21, 24], at selected periods of the year [26, 32-33], or sometimes during periods as long as a year [34-37].

Gas emissions from livestock buildings are a product of gas concentration and ventilation rates. In practice, there are two types of emissions: gross (based on the gas concentration inside a livestock building) and net (based on the difference in gas concentrations inside and outside the building), which are calculated from the equations:

$$
\begin{gathered}
E_{\text {gross }}=c_{\text {in }} \cdot V \\
E_{\text {net }}=\left(c_{\text {in }}-c_{\text {out }}\right) \cdot V
\end{gathered}
$$

...where $E_{\text {gross net }}$ is gross/net gas emission, $c_{\text {out }}$ is gas concentration inside the building, $c_{i n}$ is gas concentration outside the building, and $V$ is ventilation rate.

Net emissions are most often reported and represent true emissions from livestock production facilities. Gas concentrations are measured using various devices - from inexpensive and not very accurate methods such as detector tubes and infrared and electrochemical devices to expensive and accurate instruments like photo-acoustic spectrometers and chromatographs. In practice, the most popular are photo-acoustic spectrometers because of their mobility and accuracy.

Livestock buildings use two types of ventilation, gravitational (natural) and forced (mechanical), to remove moisture and heat and maintain air quality. The ventilation rate in buildings with mechanical systems can be determined basing on momentary percentage efficiency of the whole system that is provided by most climate controllers. Another way to calculate ventilation rate is based on the current-voltage characteristics of fans or on the curve of the temperature controlled ventilation system and temperature measurements. More complicated is determining the ventilation rates in buildings with gravitational systems. There are several methods described in the literature. One of them is the tracer gas method, 
Table 1. Ammonia, nitrous dioxide, and methane emission factors for pigs.

\begin{tabular}{|c|c|c|c|c|c|c|c|}
\hline \multirow{2}{*}{$\begin{array}{c}\text { Production } \\
\text { group }\end{array}$} & \multirow{2}{*}{$\begin{array}{l}\text { Housing } \\
\text { system }\end{array}$} & \multirow{2}{*}{ Measuring period; Country } & \multicolumn{4}{|c|}{ Emission factor } & \multirow{2}{*}{ Source } \\
\hline & & & Unit & $\mathrm{NH}_{3}$ & $\mathrm{~N}_{2} \mathrm{O}$ & $\mathrm{CH}_{4}$ & \\
\hline \multirow{24}{*}{ Fatteners } & \multirow{16}{*}{ Non- litter } & no data; United Kingdom & $\mathrm{g} \cdot \mathrm{day}^{-1} \cdot \mathrm{LU}^{-1}$ & & $0.40^{\text {a) e) }}$ & $85.0^{\text {a) e) }}$ & [45] \\
\hline & & no data; Holland & $\mathrm{mg} \cdot \mathrm{h}^{-1} \cdot \mathrm{pig}^{-1}$ & & & $1269^{\text {a) e) }}$ & [46] \\
\hline & & no data; Germany & $\mathrm{g} \cdot \mathrm{h}^{-1} \cdot \mathrm{LU}^{-1}$ & & & $0.75^{\text {a) e) }}$ & [47] \\
\hline & & no data; Germany & $\mathrm{g} \cdot \mathrm{day}^{-1} \cdot \mathrm{LU}^{-1}$ & & & $102^{\text {a) e) }}$ & [48] \\
\hline & & 5 week; Denmark & $\mathrm{g} \cdot \mathrm{day}^{-1} \cdot \mathrm{LU}^{-1}$ & $20.0^{\mathrm{g})}$ & & $14^{\mathrm{g})}$ & [21] \\
\hline & & 1 year; Germany & $\mathrm{g} \cdot \mathrm{day}^{-1} \cdot \mathrm{LU}^{-1}$ & & & $46.8^{\text {a) e) }}$ & [34] \\
\hline & & 4 months; Belgium & $\mathrm{g} \cdot \mathrm{day}^{-1} \cdot \mathrm{pig}^{-1}$ & $6.2^{\text {a) f) }}$ & $0.54^{\text {a) f) }}$ & $16.3^{\text {a) f) }}$ & [24] \\
\hline & & V-VI,IX-X; Korea & $\mathrm{mg} \cdot \mathrm{h}^{-1} \cdot \mathrm{pig}^{-1}$ & $309.2^{\text {a) e) }}$ & & & [49] \\
\hline & & IV-V,IX-XII; Italy & $\mathrm{g} \cdot \mathrm{day}^{-1} \cdot \mathrm{LU}^{-1}$ & & $3.26^{\text {a) e) }}$ & $189.8^{\text {a) e) }}$ & {$[25]$} \\
\hline & & spring, autumn and summer; Sweden & $\mathrm{g} \cdot \mathrm{h}^{-1} \cdot \mathrm{pig}^{-1}$ & $0.2^{\text {b) e) }}$ & & $1^{\text {b) e) }}$ & [26] \\
\hline & & 1 year; Poland & $\mathrm{kg} \cdot \mathrm{yr}^{-1} \cdot \mathrm{pig}^{-1}$ & $3.0^{\text {a) e) }}$ & & & [50] \\
\hline & & 1 year; Slovakia & $\mathrm{kg} \cdot \mathrm{yr}^{-1} \cdot \mathrm{pig}^{-1}$ & $2.1^{\text {a) e) }}$ & & & [36] \\
\hline & & 1 year; Belgium & $\mathrm{kg} \cdot \mathrm{yr}^{-1} \cdot \mathrm{pig}^{-1}$ & 2.2 a) e) & $0.15^{\text {a) e) }}$ & $10.4^{\text {a) e) }}$ & [51] \\
\hline & & VIII-IX; Denmark & $\mathrm{mg} \cdot \mathrm{h}^{-1} \cdot \mathrm{pig}^{-1}$ & $265.6^{\text {a) f) }}$ & & & {$[52]$} \\
\hline & & VII-IX; Poland & $\mathrm{g} \cdot \mathrm{day}^{-1} \cdot \mathrm{kg}$ b.m. ${ }^{-1}$ & & $0.03^{\text {a) e) }}$ & $0.7^{\text {a) e) }}$ & [53] \\
\hline & & VIII-XI; Denmark & $\mathrm{g} \cdot \mathrm{day}^{-1} \cdot \mathrm{pig}^{-1}$ & 5.1 a) e) & & $3.0^{\text {a) e) }}$ & {$[54]$} \\
\hline & \multirow{8}{*}{ Litter } & no data; Belgium & $\mathrm{g} \cdot$ day $^{-1} \cdot$ pig $^{-1}$ & & $0.35^{\text {de) }}$ & $1.58^{\text {de) }}$ & {$[55]$} \\
\hline & & no data; no data & $\mathrm{g} \cdot \mathrm{day}^{-1} \cdot \mathrm{pig}^{-1}$ & & & $2.77^{\text {c) f) }}$ & {$[56]$} \\
\hline & & 4 month; Belgium & $\mathrm{g} \cdot \mathrm{day}^{-1} \cdot \mathrm{pig}^{-1}$ & $13.6^{\mathrm{c} f \mathrm{f}}$ & $0.03^{\mathrm{c}) \mathrm{f}}$ & $7.39^{\mathrm{c} f \mathrm{f}}$ & [23] \\
\hline & & 4 month; Belgium & $\mathrm{g} \cdot \mathrm{day}^{-1} \cdot \mathrm{pig}^{-1}$ & $13.1^{\mathrm{d}) \mathrm{ff}}$ & 1.11 d) f) & 16.0 d) f) & [24] \\
\hline & & 4 months; Belgium & $\mathrm{g} \cdot \mathrm{day}^{-1} \cdot \mathrm{pig}^{-1}$ & $12.1^{\mathrm{c} f \mathrm{f}}$ & $1.50^{\mathrm{c}) \mathrm{f}}$ & $16.5^{\mathrm{c}) \mathrm{f}}$ & [29] \\
\hline & & VII-IX; Poland & $\mathrm{g} \cdot \mathrm{day}^{-1} \cdot \mathrm{kg}$ b.m. ${ }^{-1}$ & & $0.05^{\text {c) e) }}$ & $0.8^{\text {c) e) }}$ & [53] \\
\hline & & 1 year; Poland & $\mathrm{g} \cdot \mathrm{day}^{-1} \cdot \mathrm{LU}^{-1}$ & $47.6^{\text {c) e) }}$ & $8.60^{\text {c) e) }}$ & $199,8^{\text {c) e) }}$ & [57] \\
\hline & & 1 year; China & $\mathrm{g} \cdot \mathrm{day}^{-1} \cdot \mathrm{LU}^{-1}$ & $39.6^{\text {d) e) }}$ & & & [58] \\
\hline \multirow{4}{*}{ Sows } & \multirow{3}{*}{ Non- litter } & no data; Holland & $\mathrm{mg} \cdot \mathrm{h}^{-1} \cdot \mathrm{pig}^{-1}$ & & & $2406^{\text {b)e }}$ & [46] \\
\hline & & IV-V,IX-XII; Italy & $\mathrm{g} \cdot \mathrm{day}^{-1} \cdot \mathrm{LU}^{-1}$ & & $1.69^{\text {a) e) }}$ & $68.4^{\text {a) e) }}$ & [25] \\
\hline & & 3 months; Belgium & $\mathrm{g} \cdot \mathrm{day}^{-1} \cdot \mathrm{pig}^{-1}$ & $12.8^{b) f)}$ & $0.47^{b) \text { f) }}$ & $10.1^{\text {b) f) }}$ & [28] \\
\hline & Litter & 3 months; Belgium & $\mathrm{g} \cdot \mathrm{day}^{-1} \cdot \mathrm{pig}^{-1}$ & $9.1^{\text {c) f) }}$ & $2.3^{c) f)}$ & $9.2^{c) f)}$ & [28] \\
\hline
\end{tabular}

I,II...XII - months of the year

${ }^{\text {a) }}$ fully-slatted floor, ${ }^{\text {b) }}$ partly-slatted floor, ${ }^{\text {c) }}$ deep litter,${ }^{\text {d) }}$ shallow litter, ${ }^{\text {e) }}$ piggery, ${ }^{\text {f) }}$ experimental room, ${ }^{\text {g) }}$ climate chamber

in which carbon dioxide $\left(\mathrm{CO}_{2}\right)$, nitrous oxide $\left(\mathrm{N}_{2} \mathrm{O}\right)$, or sulfur hexafluoride $\left(\mathrm{SF}_{6}\right)$ may be used as a tracer gas [33, 38-39]. In this method it is assumed that air is completely mixed in the space of the building, and theoretically should provide the most accurate results. This is rare in livestock buildings, so it is difficult to achieve uniform distribution of the tracer gas in the building [10]. A condition of precise measurement is accurate positioning of the gasdosing devices and correct selection of sample points [40-42]. Additionally, this method is time-consuming and expensive.
Other methods are based on the balance of carbon dioxide $\left(\mathrm{CO}_{2}\right)$, moisture, or heat. They are simpler and less expensive. In these methods it is assumed that $\mathrm{CO}_{2}$, moisture and heat are produced only by animals, which may increase the uncertainty of measurement. These methods should not be used in buildings with deep litter systems [41-44]. Determining the ventilation or air exchange rates provides the greatest uncertainly in the gas emission measurements for both mechanical and natural ventilation buildings. 
Table 2. Ammonia, nitrous dioxide, and methane emission factors for dairy cows.

\begin{tabular}{|c|c|c|c|c|c|c|c|}
\hline \multirow{2}{*}{$\begin{array}{l}\text { Production } \\
\text { group }\end{array}$} & \multirow{2}{*}{$\begin{array}{l}\text { Housing } \\
\text { system }\end{array}$} & \multirow{2}{*}{ Measuring period; Country } & \multicolumn{4}{|c|}{ Emission factor } & \multirow{2}{*}{ Source } \\
\hline & & & Unit & $\mathrm{NH}_{3}$ & $\mathrm{~N}_{2} \mathrm{O}$ & $\mathrm{CH}_{4}$ & \\
\hline \multirow{21}{*}{ Dairy cows } & \multirow{18}{*}{ Non-litter } & II-V; United Kingdom & $\mathrm{g} \cdot \mathrm{h}^{-1} \cdot \mathrm{LU}^{-1}$ & $1.02^{\text {a) d) }}$ & & & [59] \\
\hline & & I,II,XI,XI; Germany & $\mathrm{g} \cdot$ day $^{-1} \cdot \mathrm{LU}^{-1}$ & & $1.6^{\text {a) d) }}$ & $232^{\text {a) d) }}$ & {$[30]$} \\
\hline & & winter; Germany & $\mathrm{g} \cdot \mathrm{h}^{-1} \cdot \mathrm{LU}^{-1}$ & $1.62^{\text {a) d) }}$ & & $16.2^{\text {a) d) }}$ & [33] \\
\hline & & 2 months; Poland & $\mathrm{kg} \cdot \mathrm{yr}^{-1} \cdot \mathrm{cow}^{-1}$ & & & $119.2^{\text {a) e) }}$ & [22] \\
\hline & & I-III, XII; Sweden & $\mathrm{g} \cdot \mathrm{h}^{-1} \cdot \mathrm{LU}^{-1}$ & $1^{\text {b) d) }}$ & & $11.4^{\text {b) d) }}$ & {$[60]$} \\
\hline & & 1 year; USA & $\mathrm{kg} \cdot \mathrm{day}^{-1} \cdot \operatorname{cow}^{-1}$ & $0.13^{\text {b) d) }}$ & $0.01^{\mathrm{b}) \mathrm{d})}$ & $0.5^{\text {b) d) }}$ & {$[35]$} \\
\hline & & summer, winter; Germany & $\mathrm{g} \cdot \mathrm{h}^{-1} \cdot \mathrm{LU}^{-1}$ & $7^{\text {b) d) }}$ & $2.4^{\text {b) d) }}$ & $32.9^{\mathrm{b}) \mathrm{d})}$ & {$[32]$} \\
\hline & & II-V; Sweden & $\mathrm{g} \cdot \mathrm{h}^{-1} \cdot \mathrm{LU}^{-1}$ & $0.90^{\text {b) d) }}$ & & $11.1^{b) d)}$ & {$[61]$} \\
\hline & & 1 year; China & $\mathrm{kg} \cdot \mathrm{yr}^{-1} \cdot \mathrm{cow}^{-1}$ & & & $132.5^{\text {a) d) }}$ & {$[62]$} \\
\hline & & V,VII,XI; Canada & $\mathrm{g} \cdot \mathrm{h}^{-1} \cdot \mathrm{LU}^{-1}$ & & & $18.1^{\text {a) d) }}$ & {$[63]$} \\
\hline & & 1 year; Switzerland & $\mathrm{g} \cdot \mathrm{h}^{-1} \cdot \mathrm{LU}^{-1}$ & $1.6^{\mathrm{b}) \mathrm{d}}$ & & & {$[42]$} \\
\hline & & 1 year; Germany & $\mathrm{g} \cdot \mathrm{day}^{-1} \cdot \mathrm{LU}^{-1}$ & $34.4^{\text {a) d) }}$ & & $353.1^{\text {a) d) }}$ & {$[37]$} \\
\hline & & no data; Spain & $\mathrm{g} \cdot \mathrm{h}^{-1} \cdot \operatorname{cow}^{-1}$ & $0.15^{\mathrm{f})}$ & & $19.1^{\mathrm{f} f}$ & {$[20]$} \\
\hline & & II-IV,IX-X; Canada & $\mathrm{g} \cdot \mathrm{h}^{-1} \cdot \mathrm{LU}^{-1}$ & $0.54^{\text {a) d) }}$ & $0.04^{\text {a) d) }}$ & $13.1^{\text {a) d) }}$ & {$[64]$} \\
\hline & & II,III,VII,VIII; Denmark & $\mathrm{g} \cdot \mathrm{day}^{-1} \cdot \mathrm{LU}^{-1}$ & $12.2^{\text {a) d) }}$ & & $205.7^{\text {a) d) }}$ & {$[27]$} \\
\hline & & 1 year; Germany & $\mathrm{g} \cdot \mathrm{h}^{-1} \cdot \mathrm{LU}^{-1}$ & $1.67^{\text {b) d) }}$ & & $12.4^{\text {b) d) }}$ & {$[65]$} \\
\hline & & V,VII,VIII; Sweden & $\mathrm{g} \cdot \mathrm{day}^{-1} \cdot \mathrm{LU}^{-1}$ & & $1.4^{\text {c) d) }}$ & $160^{\mathrm{c}) \mathrm{d})}$ & {$[66]$} \\
\hline & & IX-X; USA & $\mathrm{g} \cdot \mathrm{day}^{-1} \cdot \mathrm{LU}^{-1}$ & & $0.69^{\mathrm{c}) \mathrm{d})}$ & $290^{\text {c) d) }}$ & {$[67]$} \\
\hline & \multirow{3}{*}{ Litter } & I,XI; Nederland & $\mathrm{g} \cdot \mathrm{day}^{-1} \cdot \operatorname{cow}^{-1}$ & $32 \mathrm{~d})$ & $1.8^{\mathrm{d})}$ & $800^{\mathrm{d})}$ & {$[31]$} \\
\hline & & 2 months; Poland & $\mathrm{kg} \cdot \mathrm{yr}^{-1} \cdot \mathrm{cow}^{-1}$ & & & $123.5^{\mathrm{e})}$ & {$[22]$} \\
\hline & & spring, fall; Canada & $\mathrm{g} \cdot \mathrm{day}^{-1} \cdot \mathrm{LU}^{-1}$ & & & $354^{\text {b) d) }}$ & {$[68]$} \\
\hline
\end{tabular}

I,II...XII - months of the year

a) slatted floor with deep pit, ${ }^{\text {b) }}$ solid floor with scraper, ${ }^{\text {c) }}$ solid floor with flushing, ${ }^{\text {d) }}$ barn, ${ }^{\text {e) }}$ climate chamber

\section{Determining Gas Emission Factors}

The results of gas emissions from livestock buildings most often are presented as emission factors. Gas emission is usually expressed per animal ( $\mathrm{WE}_{\text {animal }}$ ) or per $\mathrm{kg}$ of animal body mass $\left(\mathrm{WE}_{1 \mathrm{~kg}}\right)$, and rarely per area $\left(\mathrm{m}^{2}\right)$ of livestock building $\left(\mathrm{WE}_{1 \mathrm{~m}}{ }^{2}\right)$. The gas emission factors are calculated using the following equations:

$$
\begin{gathered}
W E_{\text {animal }}=\frac{E}{n} \\
W E_{1 k g}=\frac{E}{n \cdot m} \\
W E_{1 m^{2}}=\frac{E}{a}
\end{gathered}
$$

... where $E$ is total gas emission from a livestock building, $n$ is the number of animals, $m$ is animal body mass, and $a$ is livestock building area.
Frequently emissions are expressed per LU (livestock unit $=500 \mathrm{~kg}$ ) instead of per $\mathrm{kg}$ of animal body mass. Presenting results of gas emission measurements from livestock buildings as emission factors enables a comparison of the research results or prediction of emissions from other buildings. Additionally, the conversion of gas emissions on a per $\mathrm{kg}$ of animal body mass or per LU and per $\mathrm{m}^{2}$ basis allows us to compare between different production groups or animal species. Caution is necessary when doing these conversions, making sure that animal body mass and or building area are reported and thus known in the published papers to make valid comparisons.

Determining gas emission factors from livestock buildings requires long-term measurements with high precision and reliable instruments. Emissions should be measured in different seasons to observe their seasonality and diurnal variation. Only measurements carried out continuously for several seasons in different housing systems make it possible to calculate valid emission factors that may be used to estimate emissions from other buildings. 
Table 3. Converted gases emission factors.

\begin{tabular}{|c|c|c|c|c|c|}
\hline \multirow{2}{*}{$\begin{array}{l}\text { Production } \\
\text { group }\end{array}$} & \multirow{2}{*}{$\begin{array}{l}\text { Housing } \\
\text { system }\end{array}$} & \multicolumn{3}{|c|}{$\begin{array}{l}\text { Converted emission } \\
\text { factor }\left(\mathrm{g} \cdot \mathrm{day}^{-1} \cdot \mathrm{LU}^{-1}\right)\end{array}$} & \multirow[t]{2}{*}{ Source } \\
\hline & & $\mathrm{NH}_{3}$ & $\mathrm{~N}_{2} \mathrm{O}$ & $\mathrm{CH}_{4}$ & \\
\hline \multirow{24}{*}{ Fatteners } & \multirow{16}{*}{ Non-litter } & & 0.4 & 85.0 & {$[45]$} \\
\hline & & & & 217.5 & {$[46]$} \\
\hline & & & & 18.0 & [47] \\
\hline & & & & 102.0 & {$[48]$} \\
\hline & & 20.0 & & 14.0 & [21] \\
\hline & & & & 46.8 & [34] \\
\hline & & 45.8 & 4.0 & 120.3 & {$[24]$} \\
\hline & & 49.4 & & & [49] \\
\hline & & & 3.3 & 189.8 & [25] \\
\hline & & 32.6 & & 168.0 & [26] \\
\hline & & 58.7 & & & {$[50]$} \\
\hline & & 41.1 & & & [36] \\
\hline & & 43.1 & 3.0 & 203.5 & {$[51]$} \\
\hline & & 45.0 & & & [52] \\
\hline & & & 13.5 & 357.5 & [53] \\
\hline & & 36.0 & & 21.3 & {$[54]$} \\
\hline & \multirow{8}{*}{ Litter } & & 2.5 & 11.3 & [55] \\
\hline & & & & 19.9 & {$[56]$} \\
\hline & & 97.1 & 0.2 & 52.8 & [23] \\
\hline & & 96.7 & 8.2 & 118.3 & {$[24]$} \\
\hline & & 89.3 & 11.1 & 120.0 & [29] \\
\hline & & & 23.5 & 404.5 & [53] \\
\hline & & 47.6 & 8.6 & 199.8 & [57] \\
\hline & & 39.6 & & & [58] \\
\hline
\end{tabular}

\section{Emission Factors of $\mathrm{NH}_{3}, \mathrm{~N}_{2} \mathrm{O}$, and $\mathrm{CH}_{4}$}

Many papers concerning greenhouse gases and ammonia emissions from livestock production have been published in recent years. Most of the research was done in Europe and concerns mainly pigs and dairy cows. Some of it was done in North America and Asia (mainly in China). The values of gas emission factors for pigs are shown in Table 1, and for dairy cows in Table 2.

Most studies for pigs were conducted in non-litter housing systems (with fully or partly slatted floors) due to the popularity of these housing systems in Western Europe, where the research was mainly conducted. The non-litter housing systems were characterized by lower emissions of greenhouse gases and ammonia, but also lower standards of animal welfare compared with the litter systems. Little research concerned litter housing systems, which are still the most popular in Central and Eastern

\begin{tabular}{|c|c|c|c|c|c|}
\hline \multirow{4}{*}{ Sows } & \multirow{3}{*}{ Non-litter } & & & 412.4 & [46] \\
\hline & & & 1.7 & 68.4 & [25] \\
\hline & & 63.9 & 2.4 & 50.6 & [28] \\
\hline & Litter & 45.3 & 11.4 & 46.0 & [28] \\
\hline \multirow{21}{*}{$\begin{array}{l}\text { Dairy } \\
\text { cows }\end{array}$} & \multirow{18}{*}{ Non-litter } & 24.5 & & & [59] \\
\hline & & & 1.6 & 232.0 & [30] \\
\hline & & 38.9 & & 389.5 & [33] \\
\hline & & & & 272.0 & [22] \\
\hline & & 24.3 & & 272.6 & [60] \\
\hline & & 108.3 & 8.3 & 375.0 & [35] \\
\hline & & 169.0 & 57.6 & 789.6 & [32] \\
\hline & & 21.7 & & 266.4 & [61] \\
\hline & & & & 302.5 & [62] \\
\hline & & & & 434.4 & [63] \\
\hline & & 37.2 & & & [42] \\
\hline & & 34.4 & & 353.1 & [37] \\
\hline & & 3.0 & & 382.0 & [20] \\
\hline & & 12.8 & 0.9 & 314.4 & [64] \\
\hline & & 12.2 & & 205.7 & [27] \\
\hline & & 40.1 & & 297.6 & [65] \\
\hline & & & 1.4 & 160.0 & [66] \\
\hline & & & 0.7 & 290.0 & [67] \\
\hline & \multirow{3}{*}{ Litter } & 26.7 & 1.5 & 666.7 & [31] \\
\hline & & & & 282.0 & [22] \\
\hline & & & & 354.0 & [68] \\
\hline
\end{tabular}

Europe. In published papers the gas emission factors are predominantly from fattener production and much less for sows.

Taking into account the time of research, only $20-30 \%$ of published gas emission factors were calculated based on the measurement results collected during the whole year, with the remainder carried out during a selected season or even a single month.

Also, for dairy cows the studies in non-litter housing systems were dominant, which are considered prospective solutions. Most of the studies were carried out in production conditions during which $\mathrm{NH}_{3}$ and $\mathrm{CH}_{4}$ emissions were primarily measured. About $70-80 \%$ of the measurements were made in selected periods, and the calculated emission factors do not represent an average value for the whole year.

The emission factors for $\mathrm{NH}_{3}, \mathrm{~N}_{2} \mathrm{O}$, and $\mathrm{CH}_{4}$ presented in Tables 1 and 2 were converted to the same unit $\left(\mathrm{g} \cdot \mathrm{day}^{-1} \cdot \mathrm{LU}^{-1}\right)$, which allowed showing their variability and comparing them between animal species. The gas 
emission factors expressed for one animal were converted based on the average animal body mass during the study. When the animal body mass was not given, the conversion was made according to the animal conversion fac-

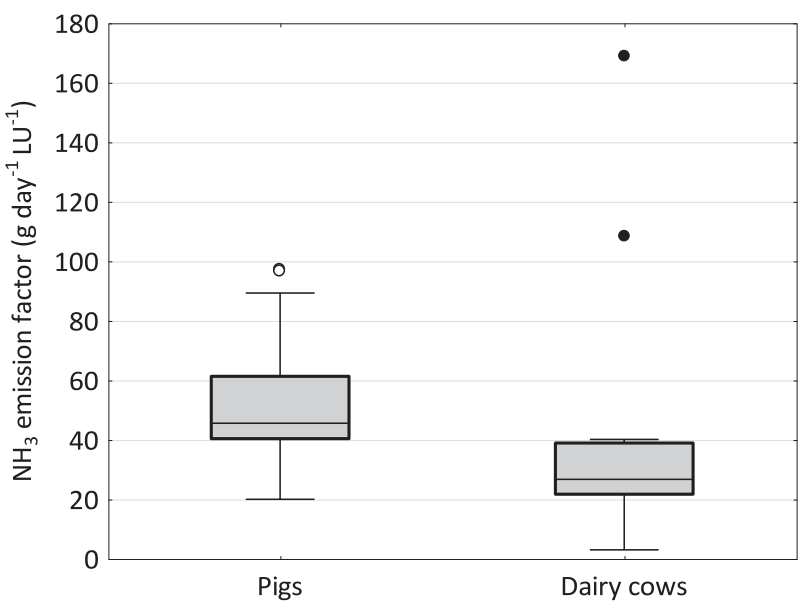

Fig. 1. The distribution of $\mathrm{NH}_{3}$ emission factors.

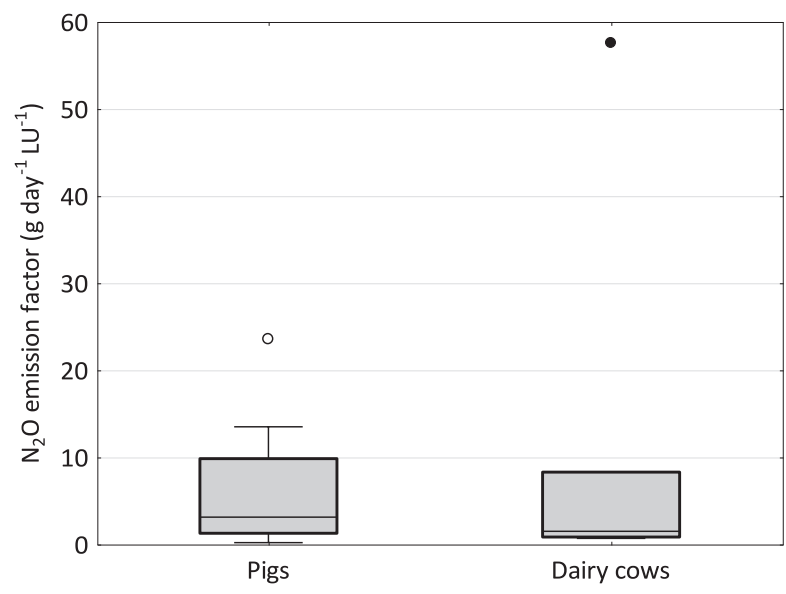

Fig. 2. The distribution of $\mathrm{N}_{2} \mathrm{O}$ emission factors.

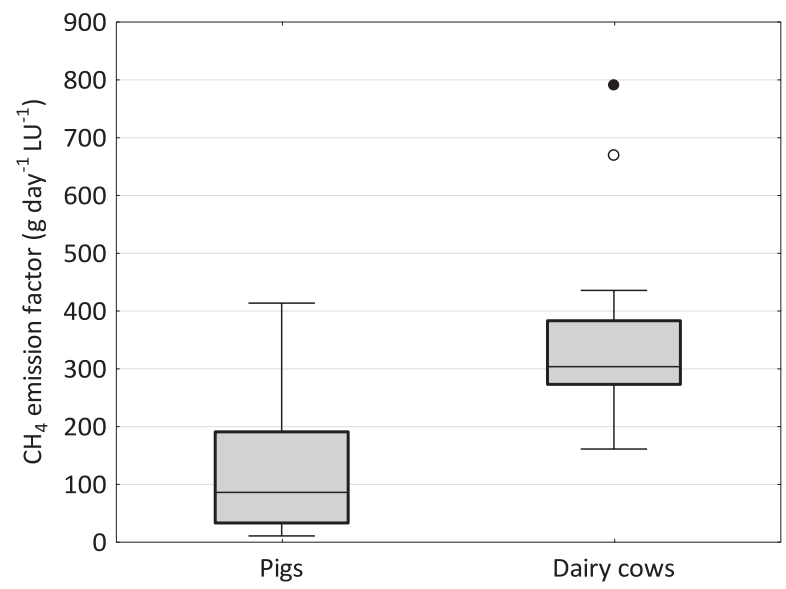

Fig. 3. The distribution of $\mathrm{CH}_{4}$ emission factors. tors from the Polish Council of Ministers' Regulation of 9 November $2010(1$ fattener $=0.14 \mathrm{LU}, 1$ sow $=0.3 \mathrm{LU}$, $1 \mathrm{cow}=1 \mathrm{LU}$ ) [69]. Although this may introduce errors, it is necessary so that comparisons between studies can be made. The converted emission factors of $\mathrm{NH}_{3}, \mathrm{~N}_{2} \mathrm{O}$, and $\mathrm{CH}_{4}$ are presented in Table 3 .

The distribution of emission factors is shown in Figs 1-3. The bottom and top of box plots indicate the first quartile (Q1) and third quartile (Q3), respectively. The lines dividing the boxes show the median, and the whiskers indicate the minimum and maximum non-outlier values. The symbol " $\bigcirc$ " represents outliers and "๑" extreme values.

The values of converted emission factors of $\mathrm{CH}_{4}$ and $\mathrm{NH}_{3}$ differ depending on the animal species. The median of $\mathrm{NH}_{3}$ emission factors for pigs $\left(45.6 \mathrm{~g} \cdot\right.$ day $\left.^{-1} \cdot \mathrm{LU}^{-1}\right)$ was almost twice that for dairy cows $\left(26.7 \mathrm{~g} \cdot \mathrm{day}^{-1} \cdot \mathrm{LU}^{-1}\right)$. A similar pattern was observed for $\mathrm{N}_{2} \mathrm{O}$. The emission factor median for pigs $\left(3.2 \mathrm{~g} \cdot \mathrm{day}^{-1} \cdot \mathrm{LU}^{-1}\right)$ was more than twice that of dairy cows $\left(1.5 \mathrm{~g} \cdot \mathrm{day}^{-1} \cdot \mathrm{LU}^{-1}\right)$. For $\mathrm{CH}_{4}$, the median of emission factors for dairy cows (302.5 $\left.\mathrm{g} \cdot \mathrm{day}^{-1} \cdot \mathrm{LU}^{-1}\right)$ was more than three times greater than for pigs $\left(85.0 \mathrm{~g} \cdot \mathrm{day}^{-1} \cdot \mathrm{LU}^{-1}\right)$. The differences of the gas emission factor values between the analyzed animal species result from many factors, including specifics of digestive systems, feed composition, building type, manure handling systems, and more.

The ranges of the converted gas emission factors were also different. For pigs it varied from 20.0 to $89.3 \mathrm{~g} \cdot \mathrm{day}^{-1} \cdot \mathrm{LU}^{-1}, 0.2$ to $13.5 \mathrm{~g} \cdot \mathrm{day}^{-1} \cdot \mathrm{LU}^{-1}$, and 9.6 to $412.4 \mathrm{~g} \cdot$ day $^{-1} \cdot \mathrm{LU}^{-1}$ for $\mathrm{NH}_{3}, \mathrm{~N}_{2} \mathrm{O}$, and $\mathrm{CH}_{4}$, respectively. The emission factors for dairy cows ranged from 3.0 to $40.1 \mathrm{~g} \cdot \mathrm{day}^{-1} \cdot \mathrm{LU}^{-1}, 0.7$ to $8.3 \mathrm{~g} \cdot \mathrm{day}^{-1} \cdot \mathrm{LU}^{-1}$, and 160.0 to $434.4 \mathrm{~g} \cdot$ day $^{-1} \cdot \mathrm{LU}^{-1}$ for $\mathrm{NH}_{3}, \mathrm{~N}_{2} \mathrm{O}$, and $\mathrm{CH}_{4}$, respectively.

Despite the use of indirect methods of determining the ventilation rate in dairy barns, which is generally characterized by greater uncertainty, ranges of emission factors of $\mathrm{NH}_{3}, \mathrm{~N}_{2} \mathrm{O}$, and $\mathrm{CH}_{4}$ were less for dairy cattle than pigs. The analysis showed a small number of outliers or extreme results, although the studies were carried out in different locations, housing systems, and duration and time of measurement.

\section{Conclusions}

Numerous papers in the literature give emissions of greenhouse gases and ammonia from livestock buildings, but the variations are large. This may be due to many reasons: geographical location, animal species, feed composition, housing and ventilation systems, and duration and time of measurements. Therefore, there is a need for experimental verification of standard emission factors used for national reporting of greenhouse gases and ammonia emissions. However, the research carried out for this purpose should be based on standardized procedures. They should primarily specify the number of measurement days during the year and specific rules for their choice. The criterion of selection of measurements 
days should not only allow for certain distribution during the year, but also consider weather conditions. Also, location of measurement points of gas concentration inside and outside the livestock building, sampling time and duration, measuring equipment, and method of determining the ventilation rate should be specified.

Moreover, the unit of gas emission factors should be standardized. The most appropriate seems to be a unit related to animal body mass (per $\mathrm{kg}$ or LU). An important element of the research is also the choice of livestock buildings, which should represent the most popular housing systems used in the country.

The emission factors will then represent the average annual emission factor more accurately, along with the national structure of livestock housing systems. Using standardized methodology will allow scientists, engineers, and other stakeholders to compare gas emission factors between livestock buildings, housing systems, countries, and animal species. In addition, the method of ventilation rate estimation for gravitationally systems needs to be improved.

\section{Acknowledgements}

Our work was co-financed by the National Center for Research and Development and carried under the project "Interdisciplinary research on improving energy efficiency and increasing the share of renewable energy sources in the energy balance of Polish agriculture" (grant No. BIOSTRATEG1/269056/5/NCBR/2015 of 11 August 2015).

\section{References}

1. GÜRLÜK S., UZEL G., TURAN Ö. Impacts of Cattle and Sheep Husbandry on Global Greenhouse Gas Emissions: A Time Series Analysis for Central European Countries. Polish Journal of Environmental Studies 24 (1), 93, 2015.

2. REES R.M., FLACK S., MAXWELL K., MISTRY A. Air: Greenhouse Gases from Agriculture. Reference Module in Food Science, from Encyclopedia of Agriculture and Food Systems. Elsevier Inc. ISBN: 978-0-08-100596-5, 293, 2014.

3. ROSZKOWSKI A. Technologies of animal production and the emission of greenhouse gases. Problemy Inżynierii Rolniczej 2, 83, 2011 [In Polish].

4. VIGURIA M., SANZ-COBEÑA A., MARÍA LÓPEZ D., ARRIAGA H., MERINO P. Ammonia and greenhouse gases emission from impermeable covered storage and land application of cattle slurry to bare soil. Agriculture, Ecosystems and Environment 199, 261, 2015.

5. ADVIENTO-BORBE M.A.A., WHEELER E.F., BROWN N.E., TOPPER P.A., GRAVE, R.E., ISHLER V.A., VARGA G.A. Ammonia and greenhouse gas flux from manure in freestall barn with dairy cows on precision fed rations. Transactions of the ASABE 53 (4), 1251, 2010.

6. MONTENY G.J., BANNINK A., CHADWICK D. Greenhouse gas abatement strategies for animal husbandry. Agriculture, Ecosystems and Environment 112, 163, 2006.

7. WRAGE N., VELTHOF G.L., VAN BEUSICHEM M.L.,
OENEMA O. Role of nitrifier denitrification in the production of nitrous oxide. Soil Biology and Biochemistry 33 (12), 1723, 2001

8. ZHU Z., DONG H., ZHOU Z., XIN H., CHEN Y. Ammonia and greenhouse gases concentrations and emissions of a naturally ventilated laying hen house in northeast China. Transactions of the ASABE 54 (3), 1085, 2011.

9. IPCC Third Assessment Report - Climate Change 2001. The Scientific Basis. Cambridge University Press, Cambridge, 2001.

10. MARCINKOWSKI T. The emission of gaseous nitrogen compounds from agriculture. Woda Środowisko Obszary Wiejskie. 31 (3), 175, 2010 [In Polish].

11. KRUPA S.V. Effects of atmospheric ammonia $\left(\mathrm{NH}_{3}\right)$ on terrestrial vegetation: A review. Environmental Pollution 124, 179, 2003.

12. LIU X.J., ZHANG Y., HAN W.X., TANG A.H., SHEN J.L., CUI Z.L., VITOUSEK P., ERISMAN, J.W., GOULDING K., CHRISTIE P., FANGMEIER A., ZHANG F.S. Enhanced nitrogen deposition over China. Nature 494, 459, 2013.

13. CLARK C.M., TILMAN D. Loss of plant species after chronic low-level nitrogen deposition to prairie grasslands. Nature 451, 712, 2008.

14. FAO „The role of livestock in climate change" Available at: http://www.fao.org/agriculture/lead/themes0/climate/en/, 2016.

15. FAO „Agri-Environmental Indicators” Available at: $\quad$ http://faostat.fao.org/site/675/DesktopDefault. aspx?PageID=675\#ancor, 2016.

16. MIELCAREK P. Verification of emission coefficients of ammonia and greenhouse gases from livestock production. Inżynieria Rolnicza 139 (4), 267, 2012 [In Polish].

17. BLANES-VIDAL V., HANSEN M.N., PEDERSEN S., ROM H.B. Emissions of ammonia, methane and nitrous oxide from pig houses and slurry: Effects of rooting material, animal activity and ventilation flow. Agriculture, Ecosystems and Environment 124, 237, 2008.

18. BLEIZGYS R., BALEŽENTIENĖ L. Assessments of Biogenic Gas Emission Processes in Cowsheds. Polish Journal of Environmental Studies 23 (4), 1107, 2014.

19. KAVOLELIS B. Impact of Animal Housing Systems on Ammonia Emission Rates. Polish Journal of Environmental Studies 15 (5), 739, 2006.

20. BARRANCOS J., BRIZ S., NOLASCO D., MELIÁN G., PADILLA G., PADRÓN E., FERNÁNDEZ I., PÉREZ N., HERNÁNDEZ P.A. A new method for estimating greenhouse gases and ammonia emissions from livestock buildings. Atmospheric Environment 74, 10, 2013.

21. KAI P., KASPERS B., VAN KEMPEN T. Modeling Sources of Gaseous Emissions in Pig House with Recharge Pit. Transactions of the ASABE 49 (5), 1479, 2006.

22. WALCZAK J., SZEWCZYK A., PAJAॄK T., RADECKI P., MAZUR D. Methane emission from different dairy housing systems. Roczniki Naukowe Zootechniki 35 (2), 187, 2008 [In Polish].

23. NICKS B., LAITAT M., FARNIR F., VANDENHEEDE M., DE' SIRON A., VERHAEGHE C., CANART B. Gaseous emissions from deep-litter pens with straw or sawdust for fattening pigs. Animal Science 78, 99, 2004.

24. PHILIPPE F.X., LAITAT M., CANART B., VANDENHEEDE M., NICKS B. Comparison of ammonia and greenhouse gas emissions during the fattening of pigs, kept either on fully slatted floor or on deep litter. Livestock Science 111, (1-2), 144, 2007.

25. COSTA A., GUARINO M. Definition of yearly emission factor of dust and greenhouse gases through continuous 
measurements in swine husbandry. Atmospheric Environment 43, 1548, 2009.

26. NGWABIE N.M., JEPPSSON K.H., NIMMERMARK S., GUSTAFSSON G. Effects of animal and climate parameters on gas emissions from a barn for fattening pigs. Applied Engineering in Agriculture 27, 1027, 2011a.

27. RONG L., LIU D., PEDERSEN E.F., ZHANG G. Effect of climate parameters on air exchange rate and ammonia and methane emissions from a hybrid ventilated dairy cow building. Energy and Buildings 82, 632, 2014.

28. PHILIPPE F.X., LAITAT M., WAVREILLE J., BARTIAUXTHILL N., NICKS B., CABARAUX J.F. Ammonia and greenhouse gas emission from group-housed gestating sows depends on floor type. Agriculture, Ecosystems and Environment 140, 498, 2011.

29. PHILIPPE F.X., LAITAT M., NICKS B., CABARAUX J.F. Ammonia and greenhouse gas emissions during the fattening of pigs kept on two types of straw floor. Agriculture, Ecosystems and Environment 150, 45, 2012.

30. JUNGBLUTH T., HARTUNG E., BROSE G. Greenhouse gas emissions from animal houses and manure stores. Nutrient Cycling in Agroecosystems 60, 133, 2001.

31. MOSQUERA J., HOL J.M.G., MONTENY G.J. Gaseous emissions from a deep litter farming system for dairy cattle. International Congress Series 1293, 291, 2006.

32. SAMER M., LOEBSIN C., FIEDLER M., AMMON C., BERG W., SANFTLEBEN P., BRUNSCH R. Heat balance and tracer gas technique for airflow rates measurement and gaseous emissions quantification in naturally ventilated livestock buildings. Energy and Buildings 43, 3718, 2011.

33. SNELL H.G.J., SEIPELT F., VAN DEN WEGHE H.F.A. Ventilation Rates and Gaseous Emissions from Naturally Ventilated Dairy Houses. Biosystems Engineering 86, (1), 67, 2003.

34. HAEUSSERMANN A., HARTUNG E., GALLMANN E., JUNGBLUTH T. Influence of season, ventilation strategy, and slurry removal on methane emissions from pig houses. Agriculture, Ecosystems and Environment 112, 115, 2006.

35. LEYTEM A.B., DUNGAN R.S., BJORNEBERG D.L., KOEHN A.C. Emissions of ammonia, methane, carbon dioxide and nitrous oxide from dairy cattle housing and manure management systems. Journal of Environmental Quality 40 (5), 1383, 2010.

36. PALKOVIČOVÁ Z., BROUČEK J., HANUS A., TONGEL P., UHRINČAŤ M., STRMEŇOVÁ A. Effect of season on ammonia emission in pig fattening. Slovak Journal of Animal Science 45, 53, 2012.

37. SCHIEFLER I. Greenhouse gas and ammonia emissions from dairy barns. PhD dissertation. Available at: http://hss. ulb.uni-bonn.de/2013/3450/3450.pdf pp. 93, 2013.

38. KITTAS C., BOULARD T., MERMIER M., PAPADAKIS G. Wind induced air exchange rate in a greenhouse tunnel with continuous side openings. Journal of Agricultural Engineering Research 65 (1), 37, 1996.

39. SEIPELT F., ROSS A., STEFFENS G., VAN DEN WEGHE $\mathrm{H}$. Monitoring of gaseous emissions from naturally ventilated dairy houses using tracer gas technique using the rate-ofdecay method. In the Proceedings of the 4th International Conference of Construction Engineering and Environment in Livestock Farming, Freising-Weihenstephan, Germany, 69, 1999.

40. BARBER E.M., OGILVIE J.R. Incomplete mixing ventilated airspaces - part I: theoretical considerations. Canadian Agricultural Engineering 24 (1), 25, 1982.

41. SAMER M., MÜLLER H., FIEDLER M., AMMON C., GLASER M., BERG W., SANFTLEBEN P., BRUNSCH R.
Developing the $85 \mathrm{Kr}$ tracer gas technique for air exchange rate measurements in naturally ventilated animal buildings. Biosystems Engineering 109 (4), 276, 2011.

42. SCHRADE S., ZEYER K., GYGAX L., EMMENEGGER L., HARTUNG E., KECK M. Ammonia emissions and emission factors of naturally ventilated dairy housing with solid floors and an outdoor exercise area in Switzerland. Atmospheric Environment 47, 183, 2012.

43. CIGR Report of Working Group on Climatization of Animal Houses - Heat and Moisture Production at Animal and House Levels. Eds S. Pedersen \& K. Sällvik: Commission International Du Genie Rural (International Commission of Agricultural Engineering). Available at: http://www.cigr.org/ CIGRWorkingGroupReports.htm, 2002.

44. PEDERSEN S., TAKAI H., JOHNSEN J. O., METZ J.H.M., KOERKAMP P., UENK G.H., PHILLIPS V.R., HOLDEN M.R., SNEATH R.W., SHORT J.L., WHITE R.P., HARTUNG J., SEEDORF J., SCHRÖDER M., LINKERT K.H.H., WATHES C.M. A comparison of three balance methods for calculating ventilation rates in livestock buildings. Journal of Agricultural Engineering Research 70 (1), 25, 1998.

45. SNEATH R.W., PHILLIPS V.R., DEMMERS T.G.M., BURGESS L.R., SHORT J.L., WELCH S.K. Long term measurements of greenhouse gas emissions from UK livestock buildings. Livestock Environment V, Proceedings of the Fifth International Symposium, Bloomington, Minnesota $5(2), 146,1997$.

46. GROOT KOERKAMP P.W.G., UENK G.H. Climatic conditions and areal pollutants in and emissions from commercial animal production systems in The Netherlands. In: Voermanns J.A.M., Monteny G.J. (Eds.) Proceedings International Symposium Ammonia and Odour Control from Animal Facilities, Vinkeloord, The Netherlands, 139, 1997.

47. GALLMANN E., HARTUNG E., JUNGBLUTH T. Assessment of two pig housing and ventilation systems regarding indoor air quality and gas emissions - diurnal and seasonal effects. Paper 00-FB-002. Proceedings: AgEng2000, Warwick, England 140, 2000.

48. GALLMANN E., HARTUNG E., JUNGBLUTH T. Longterm study regarding the emission rates of ammonia and greenhouse gases from different housing systems for fattening pigs - final results. In: Commission Internationale du Génie Rural (Eds.) Proceedings of the International Symposium on gaseous and odour emissions from animal production facilities. Horsens, Denmark 122, 2003.

49. KAI P., KASPERS B., VAN KEMPEN T. Modeling Sources of Gaseous Emissions in a Pig House with Recharge Pit. Transactions of the ASABE 49 (5), 1479, 2006.

50. WOJEWÓDZKI P. Ammonia Emission Rates from Buildings with Pigs Intensively Reared on Slats. Polish Journal of Environmental Studies 20 (5), 1343, 2011.

51. VAN RANSBEECK N., VAN LANGENHOVE H., DEMEYER P. Indoor concentration and emission factors of particulate matter, ammonia and greenhouse gases for pig fattening facilities. Biosystems Engineering 116, 518, 2013.

52. ZONG C., FENG Y., ZHANG G., HANSEN M.J. Effects of different air inlets on indoor air quality and ammonia emission from two experimental fattening pig rooms with partial pit ventilation system - summer condition. Biosystems Engineering 122, 163, 2014.

53. RZEŹNIK W., MIELCAREK P. Comparison of greenhouse gas emissions during summer from deep litter and fully-slatted piggery. Agricultural Engineering, 151 (3), 169, 2014.

54. ZONG C., LI H., ZHANG G. Ammonia and greenhouse gas emissions from fattening pig house with two types of partial 
pit ventilation systems. Agriculture, Ecosystems and Environment 208, 94, 2015.

55. BAUDOUIN N., LAITAT M., VANDENHEEDE M. Emissions of ammonia, nitrous oxide, methane, carbon dioxide and water vapor in the raising of weaned pigs on straw-based and sawdust-based deep litters. Animal Research 52, 299, 2003.

56. STOUT V., RICHARD T.L., SINGH A., HOFF S.J., DIXON P., HARMON J., BUNDY D.S. Variability in greenhouse gas emission measurements using the tracer gas technique. In: Commission Internationale du Génie Rural (Eds.) Proceedings of the International Symposium on gaseous and odour emissions from animal production facilities. Horsens, Denmark 96, 2003.

57. MIELCAREK P., RZEŹNIK W., RZEŹNIK I. Ammonia and greenhouse gas emissions from a deep litter farming system for fattening pigs. Problemy Inżynierii Rolniczej, 83 (1), 83, 2014 [In Polish].

58. XU W., ZHENG K., LIU X., MENG L., HUAITALLA R. M., SHEN J., HARTUNG E.,GALLMANN E., ROELCKE M., ZHANG F. Atmospheric $\mathrm{NH}_{3}$ dynamics at a typical pig farm in China and their implications. Atmospheric Pollution Research 5, 455, 2014.

59. DEMMERS T.G.M., PHILLIPS V.R., SHORT L.S., BURGESS L.R., HOXEY R.P., WATHES C.M. Validation of ventilation rate measurement methods and the ammonia emission from naturally ventilated dairy and beef buildings in the U.K. Journal of Agricultural Engineering Research 79, 107, 2001.

60. NGWABIE N.M., JEPPSSON K-H, NIMMERMARK S., SWENSSON C., GUSTAFSSON G. Multilocation measurements of greenhouse gases and emission rates of methane and ammonia from a naturally-ventilated barn for dairy cows. Biosystems Engineering 103, 68, 2009.

61. NGWABIE N. M., JEPPSSON K. H., GUSTAFSSON G., NIMMERMARK S. Effects of animal activity and air temperature on methane and ammonia emissions from a natu- rally ventilated building for dairy cows. Atmospheric Environment 45, 6760, 2011b.

62. GAO Z., YUAN H., MA W., LI J., LIU X, DESJARDINS R.L. Diurnal and Seasonal Patterns of Methane Emissions from a Dairy Operation in North China Plain. Advances in Meteorology 2011, 1, 2011.

63. MCGINN S.M., BEAUCHEMIN K.A. Dairy farm methane emissions using a dispersion model. Journal of Environmental Quality 41, 73, 2012.

64. NGWABIE N.M., VANDERZAAG A., JAYASUNDARA S., WAGNER-RIDDLE C.. Measurements of emission factors from a naturally ventilated commercial barn for dairy cows in a cold climate. Biosystems Engineering 127, 103, 2014.

65. SAHA C. K., AMMON C., BERG W., LOEBSIN C., FIEDLER M., BRUNSCH R., VON BOBRUTZKI K. The effect of external wind speed and direction on sampling point concentrations, air change rate and emissions from a naturally ventilated dairy building. Biosystems Engineering 114, 267, 2013.

66. JOO H.S., NDEGWA P.M., HEBER A.J., NI J.-Q., BOGAN B.W., RAMIREZ-DORRONSORO J.C., CORTUS E. Greenhouse gas emissions from naturally ventilated freestall dairy barns. Atmospheric Environment 102, 384, 2015.

67. CORTUS E.L., JACOBSON L.D., HETCHLER B.P., HEBER A.J., BOGAN B.W. Methane and nitrous oxide analyzer comparison and emissions from dairy freestall barns with manure flushing and scraping. Atmospheric Environment 100, 57, 2015.

68. VANDERZAAG A.C., FLESCH T.K., DESJARDINS R.L., BALDÉ H., WRIGHT T. Measuring methane emissions from two dairy farms: Seasonal and manure-management effects. Agricultural and Forest Meteorology 194, 259, 2014.

69. Council of Ministers Regulation of 9 November 2010 determining the types of projects that may be significantly affect to environment (J. Law 2010.213.1397) [In Polish]. 